\title{
THE ROLE OF CITIES IN THE EUROPEAN UNION CLIMATE ACTION UNDER THE EUROPEAN GREEN DEAL IN THE POST-2020 FUNDING PERIOD
}

\author{
Liliia Hrytsai \\ Uniwersytet Marii Curie-Skłodowskiej w Lublinie \\ Wydział Politologii i Dziennikarstwa \\ ORCID http://orcid.org/0000-0002-3768-451X \\ Email: lillahrytsai@gmail.com
}

\begin{abstract}
In December 2019, the European Commission has presented the European Green Deal (EGD) that aims to make the European Union climate neutral by 2050 . Accounting for $80 \%$ of the total EU population, and being responsible for $70 \%$ of GHG emissions and $75 \%$ of energy use, the European cities stay at the frontline of the ambitious and multidimensional transformation of Europe towards the first climate neutral continent. The main aim of this paper is to explore the place of European urban areas in the EU climate action under the EGD in the post-2020 funding period. The first part of this article stresses the role of cities in the EU climate transition; the following part highlights the significance of urban dimension within the EGD as a post-COVID recovery plan; and the last part presents the incorporation of climate paradigm into the urban dimension within the post-2020 financial frameworks. Results of this study shows that besides of a remarkable progress in the integration of urban dimension into the EGD, foundation of European city networks, and participation in the MFF for 2021-2027 and NGEU recovery fund, cities still require a greater support from the EU in the area of climate action.
\end{abstract}

Keywords: cities, urbanisation, European Union, European Green Deal, EU climate action.

\section{INTRODUCTION}

The European Union is widely considered as a global leader in a climate change mitigation. Just before the beginning of the COVID-19 crisis, in December 2019, the European Commission has adopted the European Green Deal (EGD) aiming to make the European Union climate neutral till 2050. In comparison with the EU's previous economic roadmap - the Europe 2020 Strategy (2010-2020) the EGD presents a new holistic strategy that aims to separate economic growth from the resource use and achieve carbon neutrality by applying sustainability 
principles in all EU policies. The Commission considers the new strategy as a chance for Europe to shoulder outstanding structural changes and to become a global leader in the renewable energy, circular economy and green technologies. The EGD's goal is to bring benefits for the biodiversity and environmental protection, quality of life, health, competitiveness and resilience as a notable part of an ambitious plan that requires the review of governance frameworks, existing policies and legislation, as well as the commitment of all EU actors [De Gregorio Hurtado 2021: 28].

The European urban areas stay at the frontline of the ambitious and complex transformations that lie ahead of Europe. Cities accumulate a number of environmental and socio-economic challenges, but their political and socio-economic power may drive the solutions to these challenges. The main goals of this paper are: (1) to explain why do we need to consider European cities as important stakeholders of the EGD as a post-COVID recovery plan, and (2) to present the opportunities for strengthening the EGD's urban dimension through the post-2020 funding period. Respectively, the main research questions of this study are the following:

RQ1: What is the place of cities in the European climate transition?

RQ2: What is the role of urban dimension in the European Green Deal as a post-COVID recovery plan?

RQ3: How to implement a climate paradigm into the urban dimension within the EU post-2020 funding frameworks?

This study consists from an introduction, three subsections, conclusions and references. An introduction part provides with the background, goals, research questions, research structure and methodology of this study. The first part highlights the significant share of cities in the EU total population, GHG emissions and energy consumption, as well as city activity across the EU in the area of EGD goals. The second part describes the urban dimension of both the Next Generation EU (NGEU) recovery instrument and Multiannual financial framework (MFF) 2021-2027 as the main tools of the EGD that aims to become a sort of "Marshall Plan for the EU". The last part stresses the issue of integration of climate approach into the urban dimension and the facilitation of local governments by the EU in their efforts to support climate transition.

Methodology of this study is based on desk review of available materials in the relevant topic. References encompass the EU official webpage, case studies, reports, scientific articles and other literature freely available through the electronic access of Maria Curie-Skłodowska library, databases of Research Gate and Google Scholar, as well as via the Internet search. The paper includes qualitative, quantitative and comparative research methods applying to analyze about 20 relevant research elaborations. 


\section{THE ROLE OF CITIES IN THE EUROPEAN CLIMATE TRANSITION}

During the time of "climate emergency", the EGD offers a vision of the EU's future that sets up a new policy discourse at a supranational level. It aims to present a path of transformation for the economy together with the environmental sustainability. From a historical perspective, this discourse is not a new one. In the early 1970s, the Club of Rome report "The Limits to Growth" stated that economic growth in a long-term is unsustainable unless it bases on the principles of environmental sustainability [Laurent 2020: 97-98]. Through the several last decades the EU has been playing the main role in the international climate politics and global environmental debates, however its progress towards the holistic paradigm proposed by the EGD has been slow. The long-term unwillingness to separate economic growth from the environmental and climate issues is a sign that the EGD's implementation will meet notable economic, industrial, societal and political opposition. It will also include technical and administrative limitations that may become the main obstacles for the Member States and EU institutions they need to overcome at the local, national and regional levels [De Gregorio Hurtado 2021: 29].

To handle these challenges, the EU has prepared a set of initiatives. Legislative changes encompass the European Climate Law adopted in March 2020, which establishes the goal of the EU achieving net-zero GHG emissions in 2050. The EU action plans and strategies include the following: launched in December 2020, the 2030 Climate Target Plan that increases the EU emissions reduction target to 55\% for 2030; and presented in March 2020, the Circular Economy Action Plan and the Biodiversity Strategy for 2030. In its turn, to non-legislative initiatives belong the European Climate Pact adopted in December 2020 [European Commission 2021a]. The European Union also created financing instruments, mainly the new Just Transition Fund, as well as devoted money for research and innovation with $35 \%$ of the Horizon Europe budget dedicated to projects addressing climate change mitigation. The EGD's implementation is especially complex due to the programme's comprehensive approach, which aims to integrate the green transition in all EU policies at all levels, and address environmental, social and economic issues in synergy. Its broad-ranging measures include policy areas from energy production to finance, mobility, industry, pollution, construction, biodiversity and agriculture [European Commission 2021b].

Approximately $80 \%$ of the EU's population live in cities. Taking into consideration political and economic power of urban areas, it becomes clear that mainly cities play a key role in achieving the ambitious plan of the von der Leyen Commission. Urban areas are known for being both the places of high concentration of challenges and at the same time places of opportunities for innovation and economic growth. The United Nations informs that cities consume about $75 \%$ of global energy and produce around $70 \%$ of GHG emissions per year [Hrytsai 2020: 45]. Their economic activity, population density and infrastructure make 
them significantly vulnerable to the impact of climate change. Nevertheless, local governments also can take a chance to become the new "climate leaders" by pioneering in design and implementation of innovative environmental actions and climate policies. Many European cities have started to plant an active role in developing local climate actions and cutting-edge environmental research projects within the EU Horizon 2020 programme. Cities like Copenhagen that has committed to carbon neutrality till 2025 within the Carbon Neutral Cities Alliance (CNCA) framework, are establishing more ambitious climate goals compared to the EU and its Member States [Jochum 2020].

The EU Commission has recognised the significance of cities and local governments for the EGD's implementation, however the EGD lacks plans for cities' involvement and multi-level governance mechanisms integrating local authorities. The newly founded Horizon Europe Mission Area for Climate-Neutral and Smart Cities constitute a key initiative recognising the importance of cities for the EU's climate goals. In September 2020, it has presented its first report "100 Climate-neutral cities by 2030 - by and for the Citizens" proposing concrete actions on how to fulfil the majority of EGD goals by financing city environmental plans and investing in the urban climate transition. The Mission Board proposed to support 100 cities with over 50,000 inhabitants in the way of their transformation towards climate-neutrality through the following decade. The main idea behind this initiative is to promote chosen cities as European and national frontrunners in the EGD's implementation and to collect relevant knowledge and experience regarding effective localisation strategies [Abdullah 2021: 15]. The Horizon Europe Mission Area for Climate-Neutral and Smart Cities is going to foster financial mechanisms and governance transformation to identify policy gaps and support local authorities. The initiative presents the following five key goals: (1) to set an agenda for the cities' transformation into innovation hubs; (2) to develop a new financing and economic model for climate policies; (3) to establish new forms of city governance and innovative participation; (4) to put in place an "integrated urban planning model"; (5) to unfold data platforms and smart systems [De Gregorio Hurtado 2021: 30].

Cities are key actors in the EGD's ambitious vision. The fundamental societal, political and economic changes are essentially relied on local-level policies and commitment of local stakeholders to construct a more sustainable Europe through more sustainable city communities. As the local level is the closest level of government to citizens, urban areas hold the capacity to raise public awareness and engagement around the green transition. At the same time cities have a chance to provide arenas for building consensus regarding necessary changes and common visions in the area of social cohesion, energy use, mobility and consumption [Hrytsai 2020: 46]. The Next Generation EU (NGEU) recovery fund play a great role for monitoring local advancements and boosting community and citizen engagement in the field of climate change and sustainable development. The active participation of cities in a holistic transformation gives the EGD good chances 
to turn Europe's green transition from a utopian dream into a reality. At the local level, for the first time the necessary social, economic and political transformations appear feasible by setting up on affordable technologies, existing knowledge, governance structures and institutional capacities, as well as by benefiting from the European urban society that is remarkably concerned with the environmental and climate challenges [Lopriore \& Vlachodimitropoulou 2021: 3].

\section{THE URBAN DIMENSION OF EUROPEAN GREEN DEAL AS A POST-COVID RECOVERY PLAN}

In March 2020, after the WHO declared COVID-19 outbreak a global pandemic, the European policy landscape has changed drastically. It is remarkable that despite the emerging crisis at the local, national and EU levels, the EGD has not been marginalised by more urgent concerns. Opposite, different institutional and non-institutional actors have defended the programme. An analysis of the media debate and vivid policy in the spring and summer of 2020 demonstrates a fundamental consensus over the central role of EGD for the EU's capacity to handle the socio-economic and health impacts of the Coronavirus pandemic. It has not only been perceived as setting Europe on a way for a healthier future, but its action plans and financing instruments have been considered as an opportunity for a sustainable, green and just recovery [Castán Broto 2021: 39-40].

The majority of EU Member States approve this vision. In March, the members of the European Council delivered a joint statement underlying the significant role of the digital transformation and the green transition in the allocation of the Next Generation EU funds to tackle the socio-economic crisis. In April, 17 EU climate and environment ministers have signed an open letter in which they stated that the EU's capacity to tackle the impact of the COVID-19 outbreak is strongly depend on its ability to fight against the pandemic with managing the low carbon transition, biodiversity loss and climate change. The opposite view had been presented in March, when 37 members of the European Parliament (MEPs) asked the Commission to postpone the EGD. However, this idea didn't find its approval, because the majority of MEPs shared the Commission and Council's view. The remarkable commitment of the majority of Member States to the EGD presents a strong intention to put the green transition at the centre of their national post-COVID recovery plans. For most of the Member States this will require the introduction of changes in their national energy and climate plans (NECPs) in the short- and medium-term perspective, as these were conducted before the establishment of the EGD [De Gregorio Hurtado 2021: 30].

As mentioned before, the European Union has introduced a range of instruments and plans to bring Europe out of the COVID-19 crisis and restore the social and economic damage caused. The NGEU plan is the most important, because it integrates the EU Recovery and Resilience Facility set by the Commission 
in May 2020, which is a kind of "Marshall Plan for the EU". The NGEU plan was created in a manner that needs recovery measures to follow to the EGD priorities. More specifically, alongside other Multiannual Financial Framework (MFF) 2021-2027 instruments, the NGEU will financially support actions in the area of climate and energy. Under these circumstances the EU Member States have fallen under the pressure that requires the rapid allocation of the available resources from 2021 to support projects targeting on the green transition [Negreiros \& Falconer 2021: 50-51].

Based on their experience with climate action, urban areas can notably contribute to the implementation of climate dimension in the EU recovery plans and instruments. The multilevel and complex nature of EU governance gives a chance in this field, as it integrates national, sub-national and European governments. The urban climate initiatives in previous and current MFFs, as well as other EU instruments that take place at local level, such as the EU's urban policy, present a great potential for driving bottom-up and top-down Europeanisation. In this context, Europeanisation is referring not only to the impact of EU institutions on the Member State's actions, but also vice versa. It is worth to mention that these bottom-up and top-down dynamics impose a positive impact on relations between the EU and local authorities enabling the further development of innovative ideas and strategies created at the local level [Sebastiano Sabato \& Mandelli 2020: 114].

At the same moment, European cities have begun to be more Europeanised due to a long history of joint development of solutions, exchange knowledge and transnational cooperation over shared challenges. Some of the most important city networks in Europe have established around urban environmental and climate issues [De Gregorio Hurtado 2021: 32]. To support these cooperation bodies, the EU Commission facilitated the creation of the European Covenant of Mayors (CoM) in 2008, which today accounts 10,198 members. The Europeanisation impact of the CoM has frequently been presented as a facilitator for the development of local capacity to adapt and mitigate the climate change in the EU Member States. There are also introduced a range of indications assessing national and regional climate strategies that benefit from the experiences of member cities and the knowledge gained within the CoM framework [Domorenok et al. 2020: 3-5].

Nevertheless, the fragmentation and tensions between Member States with different priorities that have born in the negotiations over the NGEU and MFF only increased the probability of de-Europeanisation. Moreover, the EDG highlights that all cities, regions and Member States have different capacity to address climate change issues since they do not start the green transition from the same point. If not introduce effective cohesion measures, this imbalance can worsen disparities, which will lead to the lack of consensus within and between Member States on the strategy for the EU just green transition. To support the most vulnerable regions and mitigate divisions between them, the European Commission plans to strengthen the abovementioned EGD's Just Transition Mechanism as part of its COVID-19 pandemic response [Negreiros \& Falconer 2021: 53]. 
Facilitating the role of local governments in climate action could support the advancement of EGD goals across the EU and overpass the governance challenges created by the risk of de-Europeanisation. European cooperation is determined by the national interests at the Member State level, rather than at the local level. Because of their willingness and capacity to cooperate in the field of EU urban and climate policies, cities and city networks are emerging as much-needed partners within the EU institutions to facilitate the transformation introduced by the EGD [European Committee of the Regions 2019]. The recovery plan and the EGD implementation comprise much room for strengthen partnerships between European cities and the Commission around climate issues in the post-COVID period. To facilitate the local governments' support for the EU climate actions, EU institutions and Member States need to formally admit their potential contribution, institutionalise it in concrete policy instruments and fields that will be implemented in the coming years and offer cities the essential financial sources [Castán Broto 2021: 42].

Through the last three decades cities and regions have been expecting that European institutions become more sensitive towards their interests and needs, as well as grant them a bigger role in decision-making, budgeting, and policy design and implementation. To facilitate this change in the context of the EGD, in June 2020, the Committee of the Regions (CoR) founded a new "Green Deal Going Local" working group. Its main goal is to assure that local governments are engaged in the definition, realisation and examination of EGD initiatives that contain an urban dimension. Additionally, cities and regions have demanded for more participation in the 2021-2027 MFF and NGEU. In May, European city networks in cooperation with CoR created the so-called Cohesion Alliance with more than 12,000 members to claim for a recovery plan that is fully available for all regions and cities to support the post-2020 Cohesion Policy to address socio-economic and territorial disparities. European cities and regions in the declaration from July 2020 especially asked the Commission to take into account local needs and adapt the MMF and recovery plan to bottom-up approach. Next, in October, the mayors of nine European capitals and major cities sent an open letter to the EU institutions, in which they demanded to allocate at least $10 \%$ of the recovery fund for cities and to mandate stronger role of local governments in national recovery plans. The idea of these different lobbying campaigns is twofold: on the one hand, local government give a clear signal of their willingness to contribute to the objectives of the NGEU and EGD; on the other hand, cities stress the deficit of competencies and resources, appealing for more EU support and participation in EU policy design and decision-making [De Gregorio Hurtado 2021: 35].

Answering these calls, at the 2020 Cities Forum, Elisa Ferreira - Commissioner for Cohesion and Reforms - assured that local governments would have a formal role in the implementation and design of the Cohesion Policy for the post-2020 period [European Commission 2021c]. Nevertheless, the similar promises also were given in the last programming period (2014-2020). The idea of 
engaging cities and regions requires to be presented as concrete policy systems, frameworks and instruments at the EU level. In the EDG announcing communication, the Commission took some first steps in this direction by stressing that they are going to strength urban dimension of Cohesion Policy and recognise the EU Covenant of Mayors as the leading force that Commission will pursue to support. Nevertheless, as it described before, the local-level dimension of the EGD and the instruments for its implementation in a multi-level governance organisation requires more concrete formulation. Further, Member States are required to commit to operational programmes and developing association agreements for the 2021-2027 period that ensure a full coordination with NECPs and a greater role of local governments in the delivery of the EGD. Some Member States have already started to engage cities in planning their post-2020 programmes [Laurent 2020: 100].

\section{INTEGRATION OF CLIMATE PARADIGM INTO THE URBAN DIMENSION WITHIN THE EU POST-2020 FUNDING FRAMEWORKS}

To fully develop the EGD's urban dimension, a range of city-specific approaches can be introduced into the frameworks and that will formalise the role of local governments in the NGEU and MFF 2021-2027. To become cohesive and effective, the Commission needs to pay attention to differences between cities and regions within and across Member States, as well as to facilitate integration between EGD policies and instruments, local and regional climate plans NECPs, and other important sectoral policies. Next, the EU is required to focus not only on local governments, but perceive cities within their broader functional areas by applying the territorial view that is fundamental to climate actions. The following section presents some local-level initiatives that could be especially effective in facilitating the urban dimension of EGD [European Council 2021].

Some critical opinions regarding the NGEU recovery plan claim that Member States will face significant difficulties in the funds' allocation in an efficient and responsible manner due to the COVID-19 crisis and uncertainty in its post-period. Nevertheless, delays in allocation of structural funds in some Member States in the past MFF (2014-2020) drew a special attention to this problem during the recovery budget's negotiations. On the background of these debates, an interesting prospect is the potential of local governments to allocate funding from the Green Deal and MFF instruments to policy fields that fall within urban competencies and where cities can generate more added value [De Gregorio Hurtado 2021: 36]. Cities stay on the frontline of managing the impacts of both the COVID-19 pandemic and climate change. They hold good knowledge of their inhabitants' needs, the environmental and socio-economic challenges, and the areas of actions where their engagement in the most needed. In the majority of cases, cities have also relevant experience in the implementation of EU local climate plans and 
financial instruments. The delivery of sustainable development agendas and the direct participation of municipal governments in the distribution of EU funds is facilitated by the recognition of urban areas as leaders of climate adaptation and mitigation in the Paris Agreement, the 2030 Agenda, and the Sendai Framework for Disaster Risk Reduction [Hughes 2020: 5-6].

Cities have appeared to be remarkably effective in the EU programmes implementation that directly engage the physical dimension of sustainable urban development. The NGEU and MFF can take advantage of this capacity by applying funding into urban infrastructure transformation programmes, particularly in the following areas: energy renovation of public and private buildings, waste treatment, mobility, the electrification of heating and cooling systems in public and private buildings, incentives for the establishment of municipal energy communities, the greening of public space to eliminate heat island effects, the foundation of nature-based solutions and green corridors, and finally, biodiversity recovery. So far, such projects are required to include ex-ante conditionality to ensure the carbon-neutrality ambition is met and to guarantee coherence with holistic sustainability programmes. A lot of these initiatives could be combined with the Renovation Wave for Europe adopted in October 2020 within the EGD that aims to support energy efficiency in residential and public buildings [Eurocities 2021: 1-2].

To achieve the holistic vision of EGD, the local physical and infrastructural transformations need to be strongly integrated with policies related to governance, economic and social dimensions of sustainable urbanisation. It is worth to mention that the governmental dimension of sustainable urban development appeared to be the most difficult for local governments to address in the framework of comprehensive strategies. Nevertheless, the past decade has delivered some advances in the governmental field in the context of EU urban policy tools, which highlight the need for a further support of holistic sustainable urbanisation paradigms [Bassi et al. 2021: 64-65]. From this perspective, the integrated recovery of vulnerable urban neighbourhoods - a drawn policy issue in the EU 2014-2020 period - is a relevant area of action. A social dimension of Green Deal that leaves no one behind can facilitate urban transformation, solve social challenges and create economic opportunities. Furthermore, many European cities offer local up-skilling and re-skilling programmes aiming to prepare workers for the digital and green transition, support a circular economy and provide a high level of strategic use of public funds to power transformation and, at the same time, sustain social cohesion. Cities have also great opportunities to increase public awareness on environmental and climate change issues, and boosting citizen participation and cooperation [Lopriore \& Vlachodimitropoulou 2021: 4].

Municipal institutions and social capacity building (including city residents, business, NGOs and other stakeholders) constitute another priority. Programmes are required to focus on building of local capacity across different sectors of municipal government and with specific personnel and economic resources. 
Other interdisciplinary themes include urban health and equal opportunities, e.g., improved understanding of gender dimension in policy actions. Such programmes need to especially address the needs of small cities and towns, which hold less institutional, technical or economic capacity and those that do not possess enough experience in holistic approaches related to climate governance and action [Hughes 2020: 7].

Finally, all the introduced ideas could be facilitated by integrating their climate paradigm into the urban dimension of Cohesion Policy, under which each Member State will secure at least 6\% of their European Regional Development Fund expenditure for the purposes of Integrated Sustainable Urban Development (ISUD). Instruments such as the Integrated Territorial investments (ITI), Integrated Sustainable Urban Development Strategies and Community-led Local Development (CLLD) provide a great potential for establishing synergies with EU climate policy. If, as promised, the Commission will strengthen its urban agenda in the following programming period, this would create a promising area of action. There is particularly favourable ground for establishing synergies and boosting cooperation between the Directorate-General for Regional and Urban Policy (DG REGIO) and the Directorate-General for Climate Action (DG CLIMA) [De Gregorio Hurtado 2021: 36].

\section{CONCLUSIONS}

This article presents why do we need to perceive European cities as key stakeholders of the European Green Deal (EGD) as a post-COVID recovery plan, as well as demonstrates the possibilities to strength the EGD's urban dimension in the post-2020 funding period. This study proves that long-term collaboration between cities and EU requires twofold action: on the one side, cities have a great potential and strong willingness to support the EGD and EU climate actions, but on the other side, cities highlight the deficit of relevant competences and adequate sources to effectively contribute to the European climate agenda. In order to facilitate the EU climate mitigation efforts, European cities continuously have been asking for more EU support and the right of active engagement in the EU decision-making and policy design. Besides of the great success in advancing the EU urban dimension thought the foundation of Covenant of Mayors and Horizon Europe Mission Area for Climate-Neutral and Smart Cities, engagement in the EU's MFF for 2021-2027 and NGEU recovery fund, and the activisation of local governments in the area of climate change, the European cities still require a high level of delegation and trust from the EU. To sum up, the mutual collaboration between the European Union and its cities could deliver a remarkable progress in the decarbonisation of European economy and fulfilment of EGD objectives that will support Europe in its road to become the first climate neutral continent in the world. 
Tytul: Rola miast w działaniach Unii Europejskiej na rzecz klimatu w ramach Europejskiego Zielonego Ładu w okresie finansowania po $2020 \mathrm{r}$.

Streszczenie: W grudniu 2019 r. Komisja Europejska przedstawiła Europejski Zielony Ład (EZŁ), który ma na celu doprowadzić Unię Europejską do neutralności klimatycznej do 2050 r. Reprezentując $80 \%$ populacji UE i będąc odpowiedzialnymi za 70\% emisji gazów cieplarnianych i 75\% zużycia energii, europejskie miasta pozostają najważniejszymi graczami dla implementacji ambitnej i wielowymiarowej transformacji Europy w kierunku pierwszego kontynentu neutralnego dla klimatu. Głównym celem niniejszego artykułu jest zbadanie roli europejskich obszarów miejskich w działaniach UE na rzecz klimatu w ramach EZŁ w okresie finansowania po $2020 \mathrm{r}$. W pierwszej części artykułu została przedstawiona rola miast w transformacji klimatycznej UE; w kolejnej części autor skupia się na znaczeniu wymiaru miejskiego w ramach EGD jako planu odbudowy po pandemii COVID-19; zaś ostatnia część przedstawia włączenie paradygmatu klimatycznego do wymiaru miejskiego w okresie finansowym po 2020 r. Wyniki tego badania wykazały, że oprócz znacznego postępu w integracji wymiaru miejskiego z EZŁ, tworzenia europejskich sieci miast oraz udziału w WRF na lata 2021-2027 i funduszu odbudowy NGEU, miasta nadal wymagają większego wsparcia ze strony UE w obszarze działań na rzecz klimatu.

Slowa kluczowe: miasta, urbanizacja, Unia Europejska, Europejski Zielony Ład, działania UE na rzecz klimatu.

\section{REFERENCES}

1. Abdullah H. (2021). "Introduction". In H. Abdullah (Eds.), Towards a European Green Deal with Cities: The urban dimension of the EU's sustainable growth strategy (11-23). Barcelona: Monografias Cidob.

2. Bassi A. M., Constantini V. \& Paglialunga E. (2021). "Modelling the European Union Sustainability Transition: A Soft-Linking Approach". Sustainability 13(11), 63-78. DOI: https://doi. org/10.3390/su13116303.

3. Castán Broto V. (2021). "The European Green Deal and the challenge of systemic change in urban areas". In H. Abdullah (Eds.), Towards a European Green Deal with Cities: The urban dimension of the EU's sustainable growth strategy (39-49). Barcelona: Monografias Cidob.

4. De Gregorio Hurtado S. (2021). "A Green Deal for the urban age: A new role for cities in EU climate action". In H. Abdullah (Eds.), Towards a European Green Deal with Cities: The urban dimension of the EU's sustainable growth strategy (27-38). Barcelona: Monografias Cidob.

5. Domorenok E., Acconcia G., Bendlin L. \& Campillo X. R. (2020). "Experiments in EU Climate Governance: The Unfulfilled Potential of the Covenant of Mayors". Global Environmental Politics, 20(8),1-22. DOI: https://doi.org/10.1162/glep_a_00563.

6. Eurocities (2021). „An EU budget proposal for recovery: How will funding reach cities?”. An official website of Eurocities. Retrieved from: https://nws.eurocities.eu/MediaShell/media/2020 Budget_proposal.pdf.

7. European Commission (2021a). "European Climate Law". An official website of the European Union. Retrieved from: https://ec.europa.eu/clima/policies/eu-climate-action/law_en.

8. European Commission (2021b). „Just Transition funding sources”. An official website of the European Union. Retrieved from: https://ec.europa.eu/info/strategy/priorities-2019-2024/europeangreen-deal/finance-and-green-deal/just-transition-mechanism/just-transition-funding-sources_en.

9. European Commission (2021c). "Commission welcomes the adoption of $€ 373$ billion Cohesion policy legislative package 2021-2027”. An official website of the European Union. Retrieved from: https://ec.europa.eu/commission/presscorner/detail/en/ip_21_3058. 
10. European Committee of the Regions (2019). "EU local leaders call for ambitious climate goals and adequate support from the EU". An official website of the European Union. Retrieved from: https://cor.europa.eu/pl/news/Pages/EU-local-leaders-call-for-ambitious-climate-goals-and-adequate-support-from-the-EU.aspx.

11. European Council (2021). ,Long-term EU budget 2021-2027 and recovery package”. An official website of the European Union. Retrieved from: https://www.consilium.europa.eu/en/policies/the-eu-budget/long-term-eu-budget-2021-2027/\#: :text=The\%20multiannual\%20financial $\% 20$ framework $\% 20$ (MFF,including\%20green $\% 20$ and $\% 20$ digital $\% 20$ transitions.\&text=European $\% 20$ public $\% 20$ administration $\% 3 \mathrm{~A} \% 20 \% \mathrm{E} 2 \% 82 \% \mathrm{AC} 73.1 \% 20$ billion.

12. Hrytsai L. (2020). "Cities in the Global Energy Transition: The Issue of City Leadership in the Renewable Energy Movement of the 21st Century". In D. Dylewski, R. Stachyra \& E. Dąbrowska (Eds.), Zarządzanie zasobami we wspótczesnym świecie. Wybrane zagadnienia (45-62). Łódź: ArchaeGraph.

13. Hughes S. (2020). „Climate Change and Cities”. Urban Studies, 12(3), 1-14. DOI: https://doi. org/10.1093/OBO/9780190922481-0023.

14. Jochum B. (2020). „Frontrunners on climate: just doing it”. Geneva Solutions. What happens - what works, Retrieved from: https://genevasolutions.news/climate/frontrunners-on-climatejust-do-it.

15. Laurent E. (2020). "The European Green Deal: from growth strategy to social-ecological transition?” In B. Vanhercke, S. Spasova \& B. Fronteddu (Eds.), Social policy in the European Union: state of play 2020. Facing the pandemic. Twenty-first annual report (97-104). Brussels: ETUI aisbl.

16. Laurent E. (2020). "The European Green Deal: from growth strategy to social-ecological transition?" In B. Vanhercke, S. Spasova \& B. Fronteddu (Eds.), Social policy in the European Union: state of play 2020. Facing the pandemic. Twenty-first annual report (97-104). Brussels: ETUI aisbl.

17. Lopriore M. \& Vlachodimitropoulou M. (2021). Recovery and Resilience Plans for the Next Generation EU: a unique opportunity that must be taken quickly, and carefully. Maastricht: European Institute of Public Administration.

18. Negreiros P. \& Falconer A. (2021). "Financing the green transition of European cities: what does the European Green Deal change?" In H. Abdullah (Eds.), Towards a European Green Deal with Cities: The urban dimension of the EU's sustainable growth strategy (49-60). Barcelona: Monografias Cidob.

19. Sabato S. \& Mandelli M. (2020), "Integrating the Sustainable Development Goals into the European Semester: a governance conundrum for the von der Leyen Commission?" In B. Vanhercke, S. Spasova \& B. Fronteddu (Eds.), Social policy in the European Union: state of play 2020. Facing the pandemic. Twenty-first annual report (113-127). Brussels: ETUI aisbl. 